\title{
Trichoderma spp. isolates with potential of phosphate solubilization and growth promotion in cherry tomato ${ }^{1}$
}

\author{
Danilo Vieira Cardozo França², Katia Cristina Kupper ${ }^{3}$, \\ Márcia Maria Rosa Magri², Tamara Maria Gomes ${ }^{4}$, Fabrício Rossi ${ }^{4}$
}

\section{ABSTRACT}

Trichoderma fungi are considered relevant plant growth promoters for increasing the efficiency in the use of nutrients, as well as acting as biological control agents. This study aimed to select Trichoderma spp. isolates with potential for phosphate solubilization and their application as growth promoters in interaction with homeophatic preparations, in cherry tomato. Among 16 Trichoderma spp. isolates obtained from soils of organic tomato growing areas tested in vitro, together with a commercial product (Trichodermil ${ }^{\mathbb{R}}$ ), two of them showed the ability for indole-3-acetic acid production and phosphate solubilization. The Trichoderma " $\mathrm{R}$ " had the highest mycelial growth speed index and presented twice as much spores than the commercial product. An in vivo experiment was also conducted in a greenhouse, in order to observe the potential of Trichoderma spp. isolates and homeophatic preparations on the cherry tomato growth promotion, using a randomized block experimental design, in a 4 × 3 factorial arrangement, with three Trichoderma isolates and two homeopathic preparations (Phosphorus $6 \mathrm{CH}$ and Carbo vegetabilis $6 \mathrm{CH})+$ treatment without homeopathic preparation. The leaf area and dry mass of leaves and roots were determined. It was possible to observe that the isolate "R", identified as Trichoderma asperellum, was effective in the cherry tomato growth promotion, while the homeopathic preparations applied did not show any effect.

KEYWORDS: Solanum lycopersicum L.; phosphorus; phytohormones; homeopathy.

\section{INTRODUCTION}

Trichoderma is a biocontrol agent used to improve the resistance to diseases that may also stimulate plant growth (Oliveira et al. 2016, Roese et al. 2017). Growth promotion mechanisms in plants are associated with microorganisms such as

\section{RESUMO}

Isolados de Trichoderma spp. com potencial de solubilização de fosfato e promoção de crescimento em tomateiro cereja

Fungos do gênero Trichoderma são importantes promotores de crescimento vegetal, por aumentarem a eficiência na utilização de nutrientes e atuarem como agentes de biocontrole. Objetivouse a seleção de isolados de Trichoderma spp. com potencial de solubilização de fosfato e sua aplicação como promotores de crescimento em interação com preparados homeopáticos, em tomateiro cereja. Dentre 16 isolados de Trichoderma spp. obtidos em solos de áreas de produção orgânica de tomateiro testados in vitro, em conjunto com um produto comercial (Trichodermil ${ }^{\mathbb{}}$ ), dois apresentaram produção de ácido indolacético e solubilização de fosfato. O Trichoderma " $\mathrm{R}$ " foi o isolado de maior índice de velocidade de crescimento micelial, com duas vezes mais esporos do que o produto comercial. Um experimento in vivo também foi conduzido em estufa, para verificar o potencial de isolados de Trichoderma spp. e preparados homeopáticos no crescimento de tomateiro cereja, utilizando-se delineamento experimental em blocos casualizados, em esquema fatorial $4 \times 3$, com três isolados de Trichoderma e dois preparados homeopáticos (Phosphorus 6CH e Carbo vegetabilis $6 \mathrm{CH})+$ tratamento sem homeopatia. Avaliouse a área foliar e a massa seca das folhas e das raízes. Verificou-se que o isolado "R", identificado como Trichoderma asperellum, foi eficiente na promoção de crescimento do tomateiro cereja, ao passo que os preparados homeopáticos aplicados não apresentaram efeito.

PALAVRAS-CHAVE: Solanum lycopersicum L.; fósforo; fitohormônios; homeopatia.

fungi and bacteria, which are capable of solubilizing phosphates through their metabolism, producing phytohormones or fixing nitrogen (Péres-Montaño et al. 2014).

Fungi of the Trichoderma genus are among the most studied microorganisms, due to their ability to colonize the rhizosphere and different plant organs,

1. Manuscript received in Apr./2017 and accepted for publication in Sep./2017 (http://dx.doi.org/10.1590/1983-40632017v4746447).

2. Universidade Federal de São Carlos, Centro de Ciências Agrárias, Araras, SP, Brasil.E-mails: dvcf88@hotmail.com, mrciarosa@yahoo.com.br.

3. Instituto Agronômico, Centro de Silvicultura "Sylvio de Moreira”, Cordeirópolis, SP, Brasil. E-mail: katia@centrodecitricultura.br.

4. Universidade de São Paulo, Faculdade de Zootecnia e Engenharia de Alimentos, Departamento de Engenharia de Biossistemas, Pirassununga, SP, Brasil.E-mails: tamaragomes@usp.br, fabricio.rossi@usp.br. 
promoting beneficial effects on the plant development (Carvalho et al. 2011). These fungi promote growth in plants, since some species have the ability to produce phytohormones (Carvalho et al. 2011) and solubilize phosphorus (Oliveira et al. 2012).

Phosphorus is an essential element to the metabolism and development of plants from their initial stage of life. It plays a key role in the root system growth of plants. This element is also one of the nutrients needed to promote energy transfer among cells, in the photosynthesis process (Magdoff \& Van Es 2009, Ribas et al. 2016).

Indole-3-acetic acid (IAA) is a phytohormone which belongs to the class of the auxins. It acts as a growth regulator in plants, promoting growth by stimulating mitosis, elongating existing cells or even increasing the number of plant cells. There are several microorganisms, such as Trichoderma ssp., capable of interacting with plants and synthesizing IAA through its precursor L-tryptophan (Ribas et al. 2016).

Homeopathy is the science of the similarity principle, which consists in administering to ill individuals substances that cause similar symptoms in healthy individuals (Teixeira 2012). Among numerous substances that may be employed, chosen by similarity, Carbo vegetabilis and Phosphorus stand out, the first made from charred plant material from trees and the second one from organic phosphorus salts (phosphates) (Casali et al. 2009). Carbo vegetabilis has an extensive effectiveness of action, being used in agricultural homeopathy for seed dormancy break or to recover plants that suffered with frost and other factors relating to environmental stress (Pinto et al. 2014). Phosphorus is a homeopathic treatment used in plants suffering with excessive transpiration, due to excessive heat, or even plants suffering with nutritional deficiencies and growth problems (Santos et al. 2011). It is a homeopathic preparation used to stimulate the development of tissues, buds and leaves (Toledo et al. 2015, Gonçalves et al. 2016) and may have an influence in the phosphorus absorption by plants. The $6 \mathrm{CH}$ dinamization was studied for application in plants by several researchers, showing positive effects (Rossi et al. 2006, Modolon et al. 2012, Toledo et al. 2015, Gonçalves et al. 2016, Mioranza et al. 2017).

Tomato (Solanum lycopersicum L.) (Syn.: Lycopersicon esculentum Mill.), a plant from the
Solanaceae family, is one of the most consumed vegetables in Brazil (Embrapa 2006). Among vegetables, it has one of the largest cultivated areas in the world (Carvalho et al. 2014). Studies have sought alternatives to pest and disease control (Modolon et al. 2012), crop management (Takahashi \& Cardoso 2015) and physiological disorders related to nutrition and edaphoclimatic factors (Loos et al. 2008, Costa et al. 2011). Cherry tomatoes, if compared to table tomatoes (salad, Italian or kaki), usually have a greater resistance to pests and diseases, having possibly suffered a natural selection pressure for hardness (Maciel \& Silva 2008).

Thus, this study aimed to select Trichoderma spp. isolates with a phosphate solubilization potential and use them as growth promoters in interaction with homeopathic substances, in cherry tomato.

\section{MATERIAL AND METHODS}

The experiments were performed in vitro, from January to June 2015. Soil samples were collected up to $0.20 \mathrm{~m}$ of depth, with a Dutch auger, in the rhizosphere of tomatoes, in organic tomato producing farms in Piracicaba, São Paulo state, Brazil, and stored in plastic bags.

For the Trichoderma spp. isolation, $10 \mathrm{~g}$ of each soil sample were mixed with $90 \mathrm{~mL}$ of sterile distilled water, in a $200 \mathrm{~mL}$ Erlenmeyer flask, and kept in a shaker incubator, for homogenization, for 3 hours. After this period, dilutions were performed in series with samples of up to $10^{-3}$, and $2 \mathrm{~mL}$ of this solution were applied using a modified Martin medium (Martin 1950).

The microbial growth on the plates was monitored. Successive subcultures in culture medium formulated with potato-dextrose-agar (PDA) were made to obtain seemingly pure cultures. Trichoderma spp. isolates were identified using an optical microscope, from monosporic cultures obtained from a small fragment of culture medium colonized in $10 \mathrm{~mL}$ of sterile $\mathrm{H}_{2} \mathrm{O}$, stirred and diluted up to $10^{-4}$. The conidia-diluted suspensions were applied in a PDA medium and stored in a BOD incubator, for a period of 2 days. Subsequently, isolated young colonies of Trichoderma were transferred to new Petri dishes with PDA. At the end of this procedure, 16 isolates were obtained directly from soil samples and one isolate was obtained from Trichodermil ${ }^{\circledR}$ (Trichoderma harzianum, Strain ESALQ 1306). 
Isolates were identified as A, B, C, D, E, F, G, H, I, J, L, M (Trichodermil ${ }^{\circledR}$ ), N, O, P, Q and R.

Trichoderma spp. isolates were assessed for their ability to produce IAA (Gordon \& Weber 1951). The samples were filtered to separate the mycelium from the potato-dextrose (PD). Then, $0.5 \mathrm{~mL}$ of filtered broth was pipetted into Eppendorf tubes $(2 \mathrm{~mL})$ and $0.5 \mathrm{~mL}$ of Sawkolski reagent was added. The samples were shaken for 20 minutes, to verify the discoloration in the mixture, which indicates the production of IAA. Subsequently, isolates that showed a positive staining for IAA production were subjected to a culture medium sample collection at 24, 48, 72, 96 and 144 hours, for a better study of the behavior and potential quantification of IAA production over time. Quantitation was performed by spectrophotometry, with absorbance readings at $530 \mathrm{~nm}$ (Carvalho-Filho et al. 2008). This experiment was conducted with three replicates for each sample collection time from each isolate producing IAA and one control sample.

To evaluate the phosphate solubilization capacity of the Trichoderma spp. isolates, an experiment was conducted with three replications for each sample and the control (without Trichoderma spp.). The methodology was based on Murphy \& Riley (1962), whose insoluble phosphate source is the tri-calcium phosphate $\left(\mathrm{Ca}_{3} \mathrm{HPO}_{4}\right)$. The isolates highlighted due to the phosphate solubilizing capacity were subjected one more time to a solubilization test. Collections of the phosphatic culture medium were made with Trichoderma spp. samples at 48, 96 and 144 hours, for a better observation of the phosphate solubilization potential behavior over time. Means, in each time, were compared by the Tukey test at $5 \%$, using the Sisvar 5.3 software (Ferreira 2011).

To compare the growth characteristics of Trichoderma spp. isolates, $5 \mathrm{~mm}$ fragments of colonies of each isolate were transferred to Petri dishes with PDA culture medium. The plates were kept in a BOD incubator chamber at $27^{\circ} \mathrm{C}$, during a 12-hour photoperiod. From the first day, on a daily basis, measurements of mycelium development were made, using digital calipers in an orthogonal position (Poltronieri et al. 2013). The experiment was designed with four replications for each isolate. The data were submitted to a calculation of the mycelial growth speed index (MGSI), according to the following equation: $\mathrm{MGSI}=\Sigma(\mathrm{D}-\mathrm{Dp}) \backslash \mathrm{N}$, where $D$ is the current average diameter of the colony, $D p$ the average diameter of the colony from the previous day and $N$ the number of days after inoculation. After five days of the isolates development, an evaluation of the conidia production and germination was performed. The conidia production was performed with six replicates of each isolate. For this purpose, $10 \mathrm{~mL}$ of autoclaved distilled water were added to scrape the spores, using a glass rod. The suspension was filtered using a sterile gauze to remove mycelial fragments. Subsequently, the determination of the conidium concentration was performed on each treatment, using a Neubauer chamber and an optical microscope (Dias et al. 2005). Microscope slides were prepared with a water-agar solution film (1\%), to determine the conidia germination. The conidia solution of Trichoderma "F", "R" and Trichodermil ${ }^{\circledR}$ was pipetted on these slides, at a concentration of $2 \times 10^{5}$. The slides were kept in a BOD incubator at $27{ }^{\circ} \mathrm{C}$, for 12 hours. With an optical microscope, the counting of 300 conidia was performed in each blade, registering the number of germinated spores after this period (Dias et al. 2005).

For species identification of the Trichoderma isolates "F" and "R", DNA was extracted from mycelium. DNA extraction was performed with the Reliaprep gDNA Tisse kit (Promega), according to the protocol indicated by the manufacturer, and the obtained gDNA was quantified by UV-Vis spectrophotometry, in the Nanodrop equipment. The non-coded Internal Transcribed Spacer (ITS) region of the ribosomal RNA (rRNA) gene cluster was amplified by PCR. For the amplification, a pair of degenerate primers (White et al. 1990, Toju et al. 2012) designed to cover the ITS1-ITS4 region, ranging in size $500-750 \mathrm{bp}$, between the small and large units (SSU and LSU, respectively) of the rRNA, were used. The amplified fragment was sequenced on an ABI 3500 Genetic Analyzer (Applied Biosystems) with primers forward (ITS1) and reverse (ITS4), using the Kit BigDye ${ }^{\circledR}$ Terminator v3.1 Cycle Sequencing.

An in vivo experiment was conducted in a greenhouse $\left(175 \mathrm{~m}^{2}\right)$, in Pirassununga, São Paulo state, Brazil, from July to August 2015, to observe the potential of the Trichoderma spp. isolates and the homeopathic preparations for growth promotion of cherry tomato. The experimental design was randomized blocks, in a $4 \times 3$ factorial arrangement, with three Trichoderma isolates ("F", "R" and

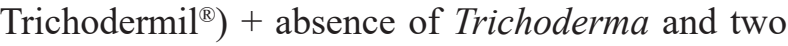
homeopathic preparations (Phosphorus $6 \mathrm{CH}$ and 
Carbo vegetabilis $6 \mathrm{CH})+$ treatment without the homeopathic preparation, to which alcohol at $30 \%$ was applied and used as a vehicle of dynamized dilutions, totaling 12 treatments, with five replications.

After liming, the chemical and particle size characterization was performed according to Embrapa (1997): $\mathrm{pH}\left(\mathrm{CaCl}_{2}\right)=6.1 ; \mathrm{Ca}=$ $45 \mathrm{mmol}_{\mathrm{c}} \mathrm{dm}^{-3} ; \mathrm{Mg}=7.0 \mathrm{mmol}_{\mathrm{c}} \mathrm{dm}^{-3} ; \mathrm{P}($ Resin $)=$ $3.0 \mathrm{mg} \mathrm{dm}^{-3} ; \mathrm{K}=0.50 \mathrm{mmol}_{\mathrm{c}} \mathrm{dm}^{-3} ; \mathrm{S}=12.0 \mathrm{mg} \mathrm{dm}^{-3}$; organic matter $=12.0 \mathrm{~g} \mathrm{dm}^{-3} ; \mathrm{V}=76.1 \% ; \mathrm{B}=$ $0.16 \mathrm{mg} \mathrm{dm}^{-3} ; \mathrm{Cu}=0.50 \mathrm{mg} \mathrm{dm}^{-3} ; \mathrm{Fe}=7.0 \mathrm{mg} \mathrm{dm}^{-3}$; $\mathrm{Mn}=2.50 \mathrm{mg} \mathrm{dm}^{-3} ; \mathrm{Zn}=0.50 \mathrm{mg} \mathrm{dm}^{-3}$; clay $=$ $341 \mathrm{~g} \mathrm{dm}^{-3}$; sand $=640 \mathrm{~g} \mathrm{dm}^{-3}$; silt $=19 \mathrm{~g} \mathrm{dm}^{-3}$.

Seedlings of wild cherry tomatoes (access 21 of the Instituto Agronômico - IAC) (Azevedo Filho \& Melo 2001) were produced in expanded polystyrene trays with a sterilized substrate. The cherry tomato seedlings were transplanted to $2.5 \mathrm{dm}^{-3}$ plastic pots at 30 days after sowing. Each pot constituted an experimental unit. The initial fertilization was made with $15 \mathrm{~g} \mathrm{dm}^{-3}$ of organic compound and phosphorus (P), at a dose of $200 \mathrm{mg} \mathrm{dm}^{-3}$ of $\mathrm{P}_{2} \mathrm{O}_{5}$, in the form of Bayóvar natural reactive phosphate $\left(14.5 \mathrm{P}_{2} \mathrm{O}_{5}\right.$, citric acid and $28.6 \%$ of total $\mathrm{P}_{2} \mathrm{O}_{5}$ ). It also contains $32 \%$ of calcium $(\mathrm{Ca})$. Potassium was provided in coverage at a dose of $100 \mathrm{mg} \mathrm{dm}^{-3}$, in the form of potassium sulphate, subdivided twice, at 15 and 22 days after transplanting (DAT). The inoculation of Trichoderma spp. was performed by adding $150 \mathrm{~mL}$ of conidia solution $\left(1 \times 10^{7}\right.$ conidia $\left.\mathrm{mL}^{-1}\right)$ immediately after transplanting.

The Carbo vegetabilis 5CH and Phosphorus $5 \mathrm{CH}$ homeopathic preparations were purchased from a homeopathic pharmacy. The dynamization $6 \mathrm{CH}$ was issued in deionized water, at the treatments application (Brasil 2011). The homeopathic treatments were diluted at $0.1 \%$ in water and $50 \mathrm{~mL}$ were applied weekly on the soil in each plot.

At 45 DAT, tomato plants were collected. The shoot was separated from the root portion and the leaves were weighed using a precision scale. The leaf area was determined in a leaf area meter Li-Cor, LI-3100C. Subsequently, all the material was dried in a forced ventilation oven at $65^{\circ} \mathrm{C}$, until constant weight.

The data were submitted to analysis of variance (Anova). Sporulation data were transformed to square root of ' $X$ ', to normalize the data. Means were compared by the Tukey or Scott-Knott test at $5 \%$, using the Sisvar 5.3 software (Ferreira 2011).

\section{RESULTS AND DISCUSSION}

Among the 17 Trichoderma spp. isolates studied, the differences which were found in 48 hours for the IAA production were obtained from the Trichoderma isolates "F" and "G", when compared to the control, by the colorimetric test (Figure 1). The remaining isolates did not show differences from the control.

By assessing the behavior of the IAA concentration, it was possible to observe that the Trichoderma " $F$ " and " $G$ " isolates had a higher IAA production after 48 hours, with $42 \mu \mathrm{g} \mathrm{L}^{-1}$ and $34 \mu \mathrm{g} \mathrm{L}^{-1}$ of IAA concentration, respectively. In the subsequent samplings at 72, 96 and 144 hours, there was a decrease at the IAA concentration in the culture medium, reaching $0 \mu \mathrm{g} \mathrm{L}^{-1}$ (Figure 2).

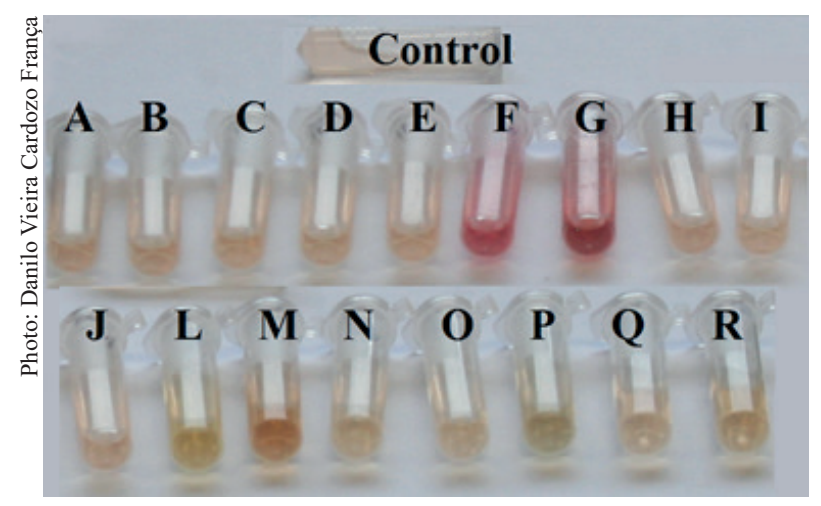

Figure 1. Comparison of Trichoderma spp. isolates by the Sakowski colorimetric test.

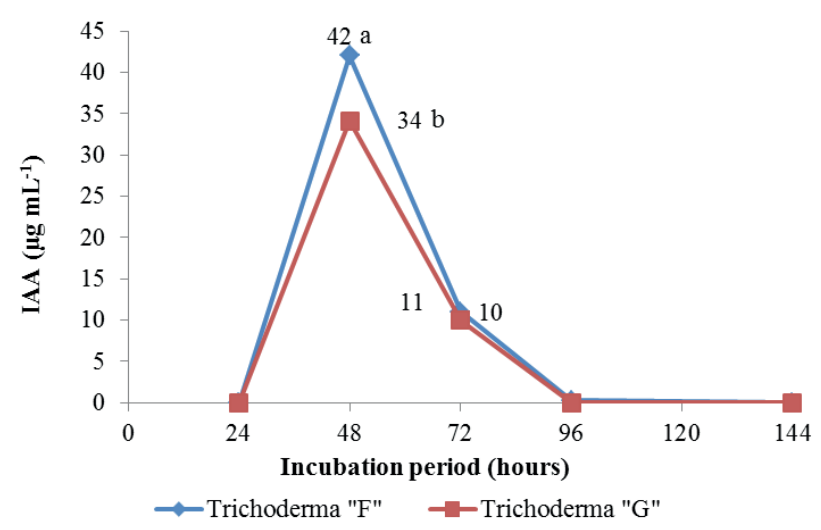

Figure 2. Concentration of indole-3-acetic acid (IAA) of Trichoderma spp. in potato-dextrose culture medium, with the addition of L-tryptophan over time. Means in 48 hours followed by different letters differ from each order by the Tukey test at $5 \%$. 
Studies conducted by Carvalho-Filho et al. (2008) showed that Trichoderma spp. isolates have detectable levels of IAA concentrations after 7 days of development in a PD culture medium. Oliveira et al. (2012) studied the production of IAA by different Trichoderma spp. isolates, using L-tryptophan over time, and found that the isolates were effective in the production of IAA with the addition of the precursor L-tryptophan in the PD medium culture, finding IAA concentrations above the ones in the present study, after the fourth day of development of the isolates in a PD medium. The IAA concentration identified in our study, with Trichoderma "F" and "G" isolates, indicated that, within 48 hours, there is a peak in the IAA production, with higher values than those found in other periods, differing from the production behavior observed by Carvalho-Filho et al. (2008) and Oliveira et al. (2012). IAA biosynthesis is tryptophan dependent (Ribas et al. 2016). Trichoderma spp. isolates were able to solubilize phosphate in a NBRIP medium, ranging 7.06-11.10 $\mu \mathrm{g} \mathrm{mL}^{-1}$ (Figure 3).

The isolates "F", "G" and "R" had the highest values for phosphate solubilization. Then, Trichodermil ${ }^{\circledR}$, "B" and "H" stood out. Regarding the $\mathrm{pH}$, it was observed that "F", "G" and Trichodermil ${ }^{\circledR}$ changed differently the medium, in relation to the other isolates, after 96 hours, acidifying the medium from 5 to 5.2 (Figure 3). It is interesting to note that the isolate "R" differed from the others, with a $\mathrm{pH}$ of 5.6, i.e., phosphate solubilization was not only influenced by reducing the $\mathrm{pH}$. Ribas et al. (2016) studied the in vitro potential for phosphate solubilization by Trichoderma spp. and concluded that the isolates showed potential for solubilization, not only acidification of the culture medium, but also the production of acid and alkaline phosphatases.

The isolate " $\mathrm{R}$ " differed within the first 48 hours from the isolates " $F$ " and "G", with higher soluble phosphate concentrations $\left(9.01 \mu \mathrm{g} \mathrm{L}^{-1}\right)$, and kept values above $10 \mu \mathrm{g} \mathrm{L} \mathrm{L}^{-1}$ up to the sixth day (144 hours) of incubation (Figure 4). All the other isolates showed a peak of solubilization at 96 hours. There was no difference regarding soluble phosphorus among the isolates at 96 and 144 hours.

Oliveira et al. (2012), evaluating the calcium phosphate solubilization capacity by Trichoderma spp. isolates in a NBRIP culture medium, at different time intervals, found, in the fourth and sixth days, that the isolates showed a higher solubilizing capacity than the ones from the previous days. After the sixth day, a significant reduction of solubilized phosphate concentration in the NBRIP medium was observed, showing that it may have been also used by fungi for their own development. Kapri \& Tewari (2010) also observed a gradual increase in the phosphorus concentration over the period between 24 hours and 96 hours of incubation. The authors subsequently reported a reduction of soluble phosphate concentrations in the culture medium. Oliveira et al. (2012) found a significant

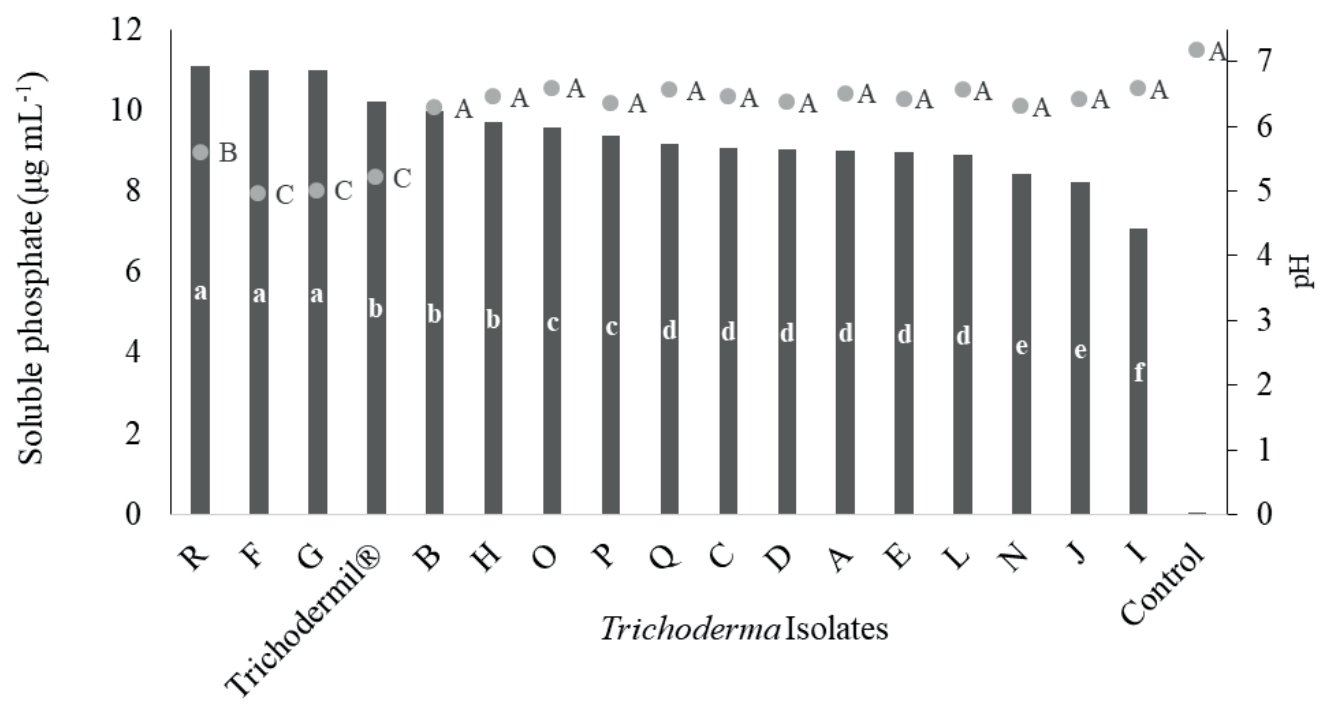

Figure 3. Average of solubilized phosphate concentration (bars) and $\mathrm{pH}$ (dots), regarding Trichoderma spp. isolates, after 96 hours of development in a NBRIP culture medium. Means followed by different letters, lowercase for soluble phosphorus and uppercase for $\mathrm{pH}$, differ by the Scott-Knott test at $5 \%$. 
reduction in the $\mathrm{pH}$ of the culture medium using phosphate-solubilizing Trichoderma sp. isolates, also associating this phosphate solubilization efficiency to this factor.

The isolate " $R$ " had the highest mycelial growth speed index. However, it did not differ from Trichodermil ${ }^{\circledR}$. The Trichoderma "F" had a growth speed $40.7 \%$ lower than the Trichoderma "R" (Table 1).

It was possible to observe that the isolate " $R$ " stood out, presenting approximately 2.5 times more spores than the isolate "F" and Trichodermil ${ }^{\circledR}$.

The isolates " $F$ " and " $R$ " were selected for further characterization, because of their growth promoting action in cherry tomato. After DNA extraction and sequencing of the non-coded Internal Transcribed Spacer (ITS) of the ribosomal RNA

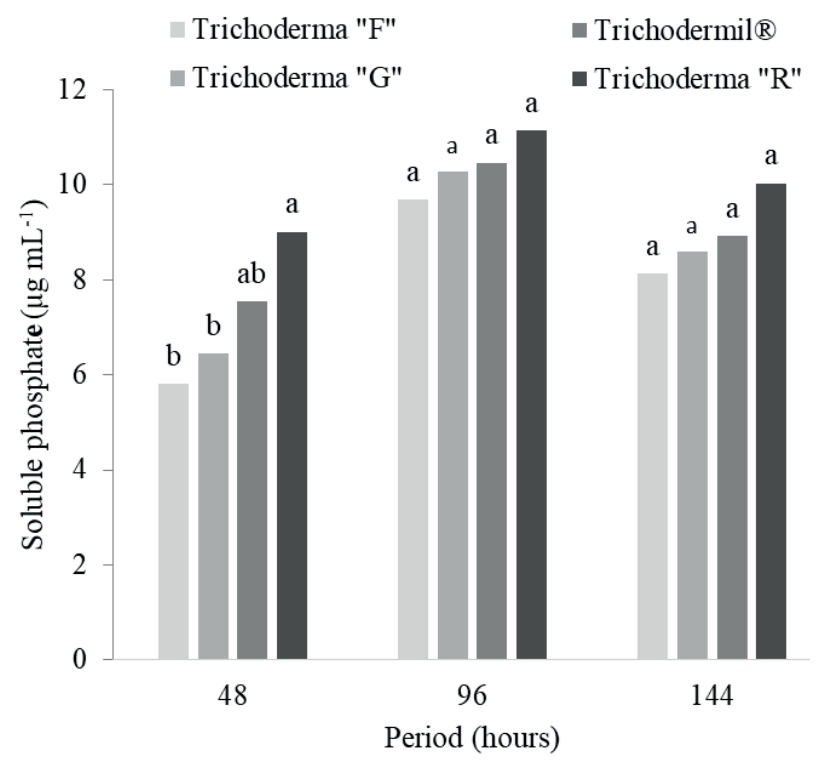

Figure 4. Average of phosphate concentration $(\mu \mathrm{g} \mathrm{mL}-1)$ solubilized by Trichoderma spp. isolates at 48, 96 and 144 hours of development in a NBRIP culture medium. Means followed by different letters at each time differ from each other by the Tukey test at $5 \%$.
(rRNA) gene cluster, the Trichoderma spp. isolates "F" and "R" were identified as Trichoderma atroviride and Trichoderma asperellum, respectively.

Regarding germination, it was observed that the isolate " $R$ " had the lowest conidia percentage after 12 hours of incubation (41.09\%), differing from the isolate "F" $(64.00 \%)$ and Trichodermil ${ }^{\mathbb{}}$ (55.42\%).

The capacity of the Trichoderma spp. ("F", Trichodermil ${ }^{\circledR}$ and " $\mathrm{R}$ ") isolates was evaluated in interaction with homeopathic treatments (Carbo vegetabilis $6 \mathrm{CH}$ and Phosphorus $6 \mathrm{CH}$ ) as growth promoters in cherry tomato. The homeopathic preparations had no effect. The effect of the homeopathic preparation is variable according to the dynamization used. Mioranza et al. (2017) studied the control of Meloidogyne incognita in tomato plants with highly diluted solutions of Thuya occidentalis $(6,12,24,50,100,200$ and $400 \mathrm{CH})$ and just $T$. occidentalis $100 \mathrm{CH}$ showed a potential for the control of M. incognita. Toledo et al. (2015) evaluated the action of the homeopathic drugs Propolis, Sulphur and Ferrum sulphuricum, at the dynamizations 6, 12, 30 and $60 \mathrm{CH}$, on the control of Alternaria solani and growth of tomato plants. Sulphur at 12 and $30 \mathrm{CH}$, Ferrum sulphuricum at 6,12 and $30 \mathrm{CH}$ and Propolis at all dilutions reduced the area under the disease progress curve by $17-49 \%$. Propolis at $30 \mathrm{CH}$ increased the fresh mass of shoots by $35 \%$ and the dry mass of roots by $38 \%$.

The isolate " $\mathrm{R}$ ", when compared with the control, influenced the parameters leaf number, total leaf area, leaf dry mass and shoot dry mass. They were higher than the control and did not differ from Trichodermil ${ }^{\circledR}$ (Table 2).

Concerning the total leaf area, the isolate " $R$ " showed a higher value $\left(272.72 \mathrm{~cm}^{2}\right)$, differing by $11 \%$, on average, from other treatments. Regarding the leaf number, leaf dry mass and shoot dry mass, the isolates " $\mathrm{R}$ " and "F" were similar to Trichodermil ${ }^{\circledR}$

Table 1. Mycelial growth speed index, sporulation and germination of Trichoderma isolates.

\begin{tabular}{lccc}
\hline \multirow{2}{*}{ Treatment } & Mycelial growth speed index & Sporulation & Germination \\
\cline { 2 - 4 } & $\mathrm{mm} \mathrm{day}{ }^{-1}$ & $\mathrm{x} \mathrm{107}$ spores $\mathrm{mL}^{-1}$ & $\%$ \\
\hline Trichoderma "F" & $36.38 \mathrm{~b}^{*}$ & $0.795 \mathrm{~b}$ & $64.00 \mathrm{a}$ \\
Trichoderma "R" $^{*}$ & $51.17 \mathrm{a}$ & $2.489 \mathrm{a}$ & $41.09 \mathrm{~b}$ \\
Trichodermil $^{\mathbb{1}}$ & $47.62 \mathrm{a}$ & $0.969 \mathrm{~b}$ & $55.42 \mathrm{a}$ \\
\hline $\mathrm{CV}(\%)$ & 6.06 & 17.29 & 12.46 \\
\hline * Means followed by different letters differ from each other by the Tukey test $(\mathrm{p} \leq 0.05)$. & &
\end{tabular}


Table 2. Leaf number, total leaf area, leaf dry mass and shoot dry mass of cherry tomato in initial culture with Trichoderma spp. isolates.

\begin{tabular}{|c|c|c|c|c|}
\hline \multirow{2}{*}{ Treatment } & Leaf number & Total leaf area & Leaf dry mass & Shoot dry mass \\
\hline & Leaves plant $^{-1}$ & $\mathrm{~cm}^{2}$ & 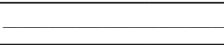 & 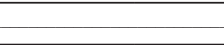 \\
\hline Control & $12.67 b^{*}$ & $238.18 \mathrm{~b}$ & $1.93 \mathrm{~b}$ & $4.12 \mathrm{~b}$ \\
\hline Trichoderma "F" & $12.33 \mathrm{~b}$ & $244.39 \mathrm{~b}$ & $2.04 \mathrm{ab}$ & $4.22 \mathrm{~b}$ \\
\hline Trichodermil $^{\circledR}$ & $13.07 \mathrm{ab}$ & $248.18 \mathrm{~b}$ & $2.07 \mathrm{ab}$ & $4.36 \mathrm{ab}$ \\
\hline Trichoderma "R" & $13.53 \mathrm{a}$ & $272.72 \mathrm{a}$ & $2.25 \mathrm{a}$ & $4.59 \mathrm{a}$ \\
\hline CV (\%) & 9.41 & 7.95 & 11.19 & 8.31 \\
\hline
\end{tabular}

* Means followed by different letters differ from each order by the Tukey test $(\mathrm{p} \leq 0.05)$.

(Table 2), however, just " $R$ " was higher than the control.

A study conducted by Aguiar et al. (2013) demonstrated that the presence of Trichoderma spp. allowed a greater accumulation of shoot fresh mass in bean plants. Such result corroborates that observed by Harman (2000), using the T-22 strain of $T$. harzianum with corn, soy and red pepper, favoring the growth promotion of plants and fruit yield. The growth promotion in plants by applying Trichoderma spp. was also observed by Silva et al. (2011), who found that isolates from different Trichoderma species and Trichodermil ${ }^{\circledR}$ were efficient in the growth promotion of cucumber plants, also inducing resistance to diseases. The results by these authors also indicated that Trichodermil ${ }^{\circledR}$ showed positive results, superior than most of the studied isolates.

The weekly application of the homeopathic preparations Carbo vegetabilis $6 \mathrm{CH}$ and Phosphorus $6 \mathrm{CH}$ did not promote the cherry tomato growth. Bastide (2004) reports that the effectiveness of the application of homeopathic treatments is based on three main factors: the matrix of information or substance to be dynamized (the information must "make sense" to the recipient); the mediator of the information, i.e., the homeopathic solution and its preparation (the medium of preparation and dynamization); and the recipient of the information, in this case the soil-plant system. Any problems in one or more of the factors may compromise the success of the treatment. Probably, in the case of this experiment, the main detected effect was the application of the Trichoderma isolate " $R$ ", which solubilized the natural phosphate, providing a proper amount of it to the tomato development.

In a study by Rossi et al. (2006), applying Carbo vegetabilis $6 \mathrm{CH}$ in lettuce, it was noted that this treatment depressed the root dry mass, if compared to the control plants. Santos et al. (2011), using a treatment with Phosphorus in different dynamizations, found that Brazilian lavender plants are sensitive to Phosphorus homeopathy and that, among dynamizations, the $21 \mathrm{CH}$ stimulated better the seed germination and plant growth.

\section{CONCLUSIONS}

1. Trichoderma spp. isolates showed an ability for the production of indole-3-acetic acid (isolates " $F$ " and "G") and solubilization of phosphate;

2. The Trichoderma asperellum " $\mathrm{R}$ " had the highest mycelial growth speed index, similarly to Trichodermil ${ }^{\circledR}$. The isolate " $R$ " presented approximately 2.5 times more spores than the isolate " $F$ " (Trichoderma atroviride) and Trichodermil ${ }^{\circledR}$, and the isolate " $\mathrm{R}$ " had the lowest percentage of conidia germination;

3. The homeopathic preparations did not affect the development of cherry tomato shoots;

4. The Trichoderma " $\mathrm{R}$ " isolate showed promising results in the promotion of tomato growth, similarly to Trichodermil ${ }^{\circledR}$.

\section{REFERENCES}

AGUIAR, A. R. et al. Seleção de isolados de Trichoderma spp. na promoção de crescimento de mudas do feijoeiro cv. Carioca e controle de Sclerotinia sclerotiorum. Ciência e Natura, v. 34, n. 2, p. 47-58, 2013.

AZEVEDO FILHO, J. A.; MELO, A. M. T. Avaliação de tomate silvestre do tipo cereja. Horticultura Brasileira, v. 19, suppl., 2001. 1 CD-ROM.

BASTIDE, M. The corporeal signifier theory (A. Lagache): application to the succussed high dilution research and homeopathy. 2004. Available at: <http://www.giriweb. $\mathrm{com} /$ download/The\%20Corporeal\%20Signifier $\% 20$ Theory.pdf $>$. Access on: 27 Nov., 2015. 
BRASIL. Farmacopéia homeopática brasileira. 2011. Available at: <http://www.anvisa.gov.br/hotsite/ farmacopeiabrasileira/conteudo/3a_edicao.pdf $>$. Access on: Nov. 2014.

CARVALHO, C. R. F. et al. Viabilidade econômica e de risco da produção de tomate no município de Cambuci/RJ. Ciência Rural, v. 44, n. 12, p. 2293-2299, 2014.

CARVALHO, D. D. C. et al. Controle de Fusarium oxysporum f.sp. phaseoli in vitro e em sementes, e promoção do crescimento inicial do feijoeiro comum por Trichoderma harzianum. Tropical Plant Pathology, v. 36, n. 1, p. 28-34, 2011.

CARVALHO-FILHO, M. R. et al. Avaliação de isolados de Trichoderma na promoção de crescimento, produção de ácido indolacético in vitro e colonização endofitica de mudas de eucalipto. Brasília, DF: Embrapa, 2008. (Boletim de pesquisa e desenvolvimento, 226).

CASALI, W. D. C.; ANDRADE, F. M. C.; DUARTE, E. S. M. Acologia de altas diluições. Viçosa: Universidade Federal de Viçosa, 2009.

COSTA, C. A. et al. Productivity of determinate growth tomato lines tolerant to heat under the organic system. Horticultura Brasileira, v. 29, n. 4, p. 590-593, 2011.

DIAS, M. D. et al. Efeito da temperatura no crescimento micelial, produção e germinação de conídios de Colletotrichum spp. isolados de Coffea arabica L. Ciência e Agrotecnologia, v. 29, n. 3, p. 545-552, 2005.

EMPRESA BRASILEIRA DE PESQUISA AGROPECUÁRIA (Embrapa). Centro Nacional de Pesquisa de Solos. Manual de métodos de análise de solos. 2. ed. Rio de Janeiro: Embrapa, 1997.

EMPRESA BRASILEIRA DE PESQUISA AGROPECUÁRIA (Embrapa). Cultivo de tomate para industrialização. 2006. Available at: <http:// sistemasdeproducao.cnptia.embrapa.br/FontesHTML/ Tomate/TomateIndustrial_2ed/>. Access on: Mar. 2015.

FERREIRA, D. F. Sisvar: a computer statistical analysis system. Ciência e Agrotecnologia, v. 35, n. 6, p. 10391042, 2011.

GONÇALVES, P. A. S.; BOFF, P.; ARAÚJO, E. R. Altas diluições de Solanum lycopersicum e Camellia sinensis no manejo fitossanitário e rendimento de cebola em sistema orgânico. Revista de Homeopatia, v. 79, n. 3, p. 1-10, 2016.

GORDON, S. A.; WEBER, R. P. Colorimetric estimation of indoleacetic acid. Plant Physiology, v. 26, n. 1, p. 192195, 1951.

HARMAN, G. E. Myths and dogmas of biocontrol: changes in perceptions derived from research on Trichoderma harzianum T-22. Plant Disease, v. 84, n. 4, p. 377-393, 2000.
KAPRI, A.; TEWARI, L. Phosphate solubilization potential and phosphatase activity of rhizospheric Trichoderma spp. Brazilian Journal of Microbiology, v. 41, n. 3, p. 787-795, 2010.

LOOS, R. A. et al. Identificação e quantificação dos componentes de perdas de produção do tomateiro em ambiente protegido. Horticultura Brasileira, v. 26, n. 2 , p. 281-286, 2008.

MACIEL, G. M.; SILVA, E. C. Herança do formato do fruto em tomateiro do grupo cereja. Horticultura Brasileira, v. 26, n. 4, p. 495-498, 2008.

MAGDOFF, F.; VAN ES, H. Building soils for better crops: sustainable soil management. 3. ed. Brentwood: USDA, 2009.

MARTIN, J. P. Use of acid, rose bengal, and streptomycin in the plate method for estimating soil fungi. Soil Science, v. 69, n. 3, p. 215-232, 1950.

MIORANZA, T. M. et al. Control of Meloidogyne incognita in tomato plants with highly diluted solutions of Thuya occidentalis and their effects on plant growth and defense metabolism. Semina: Ciências Agrárias, v. 38, n. 4, p. 2187-2200, 2017.

MODOLON, T. A. et al. Homeopathic and high dilution preparations for pest management to tomato crop under organic production system. Horticultura Brasileira, v. 30, n. 1, p. 51-57, 2012.

MURPHY, J.; RILEY, J. P. A modified single solution method for determination of phosphate in natural waters. Analytica Chimica Acta, v. 27, n. 1, p. 31-36, 1962.

OLIVEIRA, G. O. et al. Potencial de solubilização de fosfato e produção de AIA por Trichoderma spp. Revista Verde de Agroecologia e Desenvolvimento Sustentável, v. 7, n. 3, p. 149-155, 2012.

OLIVEIRA, P. et al. Resposta de fungos e processos biológicos do solo a resíduos vegetais em sistema plantio direto. Pesquisa Agropecuária Tropical, v. 46, n. 1, p. 57 64, 2016.

PÉRES-MONTAÑO, F. et al. Plant growth promotion in cereal and leguminous agricultural important plants: from microorganism capacities to crop production. Microbiological Research, v. 169, n. 5, p. 325-336, 2014.

PINTO, R. J. et al. Germinação e crescimento inicial de mangaba (Hancornia speciosa Gomes) em função de preparados homeopáticos Carbo vegetabilis e dias após o despolpamento para semeadura. Revista Agrarian, v. 7, n. 24, p. 244-250, 2014.

POLTRONIERI, T. P. S.; AZEVEDO, L. A. S.; SILVA, D. E. M. Efeito da temperatura no crescimento micelial, produção e germinação de conídios de Colletotrichum 
gloeosporioides, isolados de frutos de palmeira Juçara (Euterpe edulis Mart). Summa Phytopathologica, v. 39, n. 4, p. 281-285, 2013.

RIBAS, P. P. et al. In vitro potential for phosphate solubilization by Trichoderma spp. Brazilian Journal of Biosciences, v. 14, n. 2, p. 70-75, 2016.

ROESE, A. D. et al. Trichoderma nativo cultivado em grãos de aveia controla o tombamento e aumenta a altura da soja. Pesquisa Agropecuária Tropical, v. 47, n. 1, p. 102-109, 2017.

ROSSI, F. et al. Aplicação do medicamento homeopático Carbo vegetabilis e desenvolvimento das mudas de alface. Cultura Homeopática, v. 17, n. 1, p. 14-17, 2006.

SANTOS, F. M. et al. Germinação e crescimento de plântulas de alfazema-brasileira tratadas com homeopatia Phosphorus. Cadernos de Agroecolologia, v. 6, n. 2, p. 1-5, 2011.

SILVA, V. N. et al. Promoção de crescimento e indução de resistência à antracnose por Trichoderma spp. em pepineiro. Pesquisa Agropecuária Brasileira, v. 46, n. 12, p. 1609-1618, 2011.
TAKAHASHI, K.; CARDOSO, A. Produção e qualidade de mini tomate em sistema orgânico com dois tipos de condução de hastes e poda apical. Horticultura Brasileira, v. 33, n. 4, p. 515-520, 2015.

TEIXEIRA, M. Z. Rebound effect of drugs: fatal risk of conventional treatment and pharmacological basis of homeopathic treatment. International Journal of High Dilution Research, v. 11, n. 39, p. 69-106, 2012.

TOJU, H. et al. High-coverage ITS primers for the DNAbased identification of ascomycetes and basidiomycetes in environmental samples. PLOS ONE, v. 7, n. 7, p. 1-11, 2012.

TOLEDO, M. V.; STANGARLIN, J. R.; BONATO, C. $\mathrm{M}$. Control of early blight and effect on growth variables of tomato plants by using homeopathic drugs. Summa Phytopathologica, v. 41, n. 2, p. 126-132, 2015.

WHITE, T. J. et al. Amplification and direct sequencing of fungal ribosomal RNA genes for phylogenetics. In: INNIS, M. A. et al. (Eds.). PCR protocols: a guide to methods and applications. San Diego: Academic Press, 1990. p. 315-322. 